\title{
Prewencja zachowań samobójczych jako zadanie polityki zdrowia publicznego. Doświadczenia Finlandii, inspiracja dla Polski?
}

\begin{abstract}
Streszczenie
Złożoność i niejednoznaczność zjawiska samobójstwa to główne czynniki utrudniające planowanie i wdrażanie działań zapobiegających zachowaniom suicydalnym. Zidentyfikowane w badaniach i opisane w literaturze przedmiotu czynniki ryzyka przybliżają jednak do tworzenia skutecznych strategii prewencyjnych, co wydaje się niezbędne, szczególnie w krajach o wysokich wskaźnikach samobójstw. Strategie te są wielowymiarowe i obejmują działania na różnych poziomach, a kierowane są zarówno do specyficznych grup docelowych (osób zagrożonych samobójstwem oraz grup zawodowych, które mogą wspierać takie osoby), jak i do społeczności lokalnych czy całego społeczeństwa (by uświadamiać zbiorowość na temat zdrowia psychicznego i zachowań samobójczych). W celu skutecznego opracowania strategii, dostosowanej do specyficznych warunków środowiskowych, niezbędne jest przeprowadzenie szczegółowej eksploracji zjawiska zachowań samobójczych, co następnie pozwala wdrażać rozwiązania oparte na dowodach naukowych (evidence-based policy). Niniejszy artykuł omawia proces badań, opracowania i wdrażania strategii
\end{abstract}

1 Uniwersytet Łódzki, Wydział Ekonomiczno-Socjologiczny, e-mail: paulina.maria.adamczyk@wp.pl, https://orcid.org/0000-0002-8907-5038

2 Uniwersytet Łódzki, Wydział Ekonomiczno-Socjologiczny, e-mail: wojciech.wozniak@uni.lodz.pl, https://orcid.org/0000-0002-9720-6595 
zapobiegania samobójstwom w Finlandii oraz jej funkcjonowania od lat 90. XX w., a także roli w polityce publicznej. W tym kontekście omówiony został znaczny spadek wskaźnika samobójstw w Finlandii w tym okresie, a fiński przypadek potraktowany został jako potencjalna inspiracja dla profilaktyki zachowań samobójczych w Polsce.

Słowa kluczowe: polityka zdrowotna, polityka publiczna, zdrowie publiczne, zapobieganie samobójstwom, zdrowie psychiczne, Finlandia

Kody klasyfikacji JEL: I00, I18, I12, O57

\title{
Suicide prevention as a task of public health policy: Finland's experience, inspiration for Poland?
}

\begin{abstract}
The complexity and ambiguity of suicide are the main factors hampering the development of fully effective measures against suicidal behavior. Nonetheless, risk factors identified in the scientific literature allow for creating more and more effective preventive strategies, which seems essential, particularly in countries with high suicide rates. The most effective strategies are multidimensional and operate on a different level, addressing specific target groups (those at risk of suicide, and those professionals who may offer support to them), as well as local communities and society as a whole (to increase awareness about mental health and suicidal behavior). In order to develop effective strategies, tailored to specific societal needs, the in-depth exploration of the phenomena is needed, which may lead to planning evidence-based policies. This article elaborates on the process of research, development, and implementation of the suicide prevention strategy in Finland since the mid-1980s and its role in public policy. The decline in suicide rates in Finland is addressed in this context and the potential inspiration for the Polish suicide prevention is discussed.
\end{abstract}

Keywords: healthcare policy, public policy, public health, suicide prevention, mental health, Finland

JEL Classification Codes: I00, I18, I12, O57

Jeden na czterdzieści zgonów to samobójstwo, jest to dziesiąta najczęstsza przyczyna śmierci na świecie (Erling, 2019; WHO, 2021). Szacuje się, że każde samobójstwo dodatkowo oddziałuje na „co najmniej cztery osoby bezpośrednio, a do 20 osób pozostających w pośrednim kontakcie z osobą samobójcy” (Hołyst, 2012: 1176). Powiązania te mają różny charakter - od zależności ekonomicznych po obciążenia emocjonalne. Wśród najbliższych osoby popełniającej samobójstwo pojawiają się 
nie tylko trudności związane z przeżywaniem żałoby czy redefinicją ról w rodzinie, ich także często dotykają myśli samobójcze (Czabański, 2019).

Wśród przedstawicieli różnych dyscyplin naukowych panuje zgoda co do złożoności i istotności tego zjawiska jako wyzwania dla polityki zdrowotnej. Zgodnie z danymi i rekomendacjami Światowej Organizacji Zdrowia (WHO) oraz Międzynarodowej Organizacji na rzecz Zapobiegania Samobójstwom (International Association for Suicide Prevention - IASP) z wyzwaniem tym można i trzeba radzić sobie prewencyjnie (Lewitzka et al., 2019: 1). Ponieważ jest to zjawisko wielowymiarowe, a na jego skalę i częstotliwość ma wpływ szerokie spektrum czynników, należy je analizować z różnych perspektyw: medycznej, psychologicznej, społecznej (zatem socjologicznej), edukacyjnej oraz politycznej.

Skuteczne działania profilaktyczne powinny być podejmowane w szerokim zakresie i na różnych poziomach - podążając od szczegółu, czyli bezpośredniej pomocy jednostce w sytuacji presuicydalnej, do ogółu, a więc edukacji i uwrażliwienia na tę kwestię całego społeczeństwa (Zwoliński, 2013: 263-264). Podobnie jak edukacja w zakresie utrzymywania dobrego zdrowia, rozpoznawania niepokojących objawów somatycznych czy wiedzy o możliwych negatywnych skutkach przyjmowania leków, niezbędne jest dbanie o psyche, która często stanowi podłoże dolegliwości fizycznych (Hołyst, 2012: 1194-1200).

Wyniki badań jakościowych stanowią istotny argument za wdrażaniem złożonej strategii prewencyjnej, której działania muszą obejmować populację na różnych poziomach. Okazuje się bowiem, że przewidywanie czy też modelowanie tzw. sylwetki samobójcy jest w zasadzie niemożliwe. Analiza pozostawionych listów pożegnalnych (zob. Witkowska, 2021) czy narracji osób po próbach samobójczych (zob. Ziółkowska, 2016), w których jednostki w mniej lub bardziej szczegółowy sposób opisują powody swojej decyzji, wskazuje jedynie na pewne czynniki ryzyka, podobnej wiedzy dostarczają doświadczenia praktyków (psychiatrów, psychologów, psychoterapeutów czy interwentów kryzysowych). Na jej podstawie można opracować pewne schematy działania, niewyczerpujące jednak pełnego spektrum możliwych okoliczności podjęcia prób samobójczych (schematy niekiedy mogą zawęzić postrzeganie potencjalnych sytuacji kryzysowych i przyczynić się do zlekceważenia czynników niemieszczących się w zdefiniowanej „puli”). Wdrażanie działań prewencyjnych na różnych szczeblach wyzwalać może efekt synergii przyczyniającej się do zauważalnego spadku wskaźnika samobójstw (van der Feltz-Cornelis et al., 2011; Hoffstra et al., 2020).

Prewencję skierowaną do grup ryzyka warto dokładnie zbadać w celu empirycznego zweryfikowania przyjętych założeń i zminimalizowania zagrożenia wynikającego z pogorszenia stanu jednostek w kryzysie na skutek podjęcia niewłaściwych oddziaływań. Skuteczność takiego działania potwierdza program Columbia Teen Screen 
powstały w latach 90. XX w. i realizowany przez Uniwersytet Columbia do $2012 \mathrm{r}$. Program skierowany był do uczniów i składał się z trzech etapów - w pierwszym uczestniczyli wszyscy badani, była to ankieta dotycząca zdrowia (health survey). Jednostki zidentyfikowane jako zagrożone samobójstwem brały udział w kolejnych etapach, tj. w szczegółowym wywiadzie diagnostycznym (Diagnostic Interview Schedule for Children), a następnie w rozmowie ze specjalistą (Shaffer et al., 2004; Joe, Bryant, 2007). Znacznego odsetka jednostek nie objęto wcześniej wsparciem, ponieważ nie były one „zdiagnozowane” jako osoby w kryzysie (Fox, 2016).

Ilustracją dobrze zaprojektowanych i wdrożonych rozwiązań z zakresu polityki publicznej może być przykład Finlandii, gdzie liczba samobójstw w latach 1990-2015 obniżyła się ponad dwukrotnie (z 26,96 na 100 tys. mieszkańców do 12,62 na 100 tys. mieszkańców). Wciąż jest minimalnie wyższa niż średnia dla krajów Unii Europejskiej, ale wielokrotnie w tym okresie wyższy wskaźnik samobójstw miała Polska (Global Burden of Disease, 2018). Przede wszystkim jednak w analogicznym okresie wskaźnik samobójstw w Polsce ledwie drgnął - i to niestety, pogarszając się (13,57 w $1990 \mathrm{r}$. do 13,95 w 2015 r. $)^{3}$. Rozkład danych z lat 1990-2017 przedstawia rysunek 1.

\section{Rysunek 1. Liczba samobójstw na 100 tys. mieszkańców w Polsce i Finlandii w latach 1990-2017}

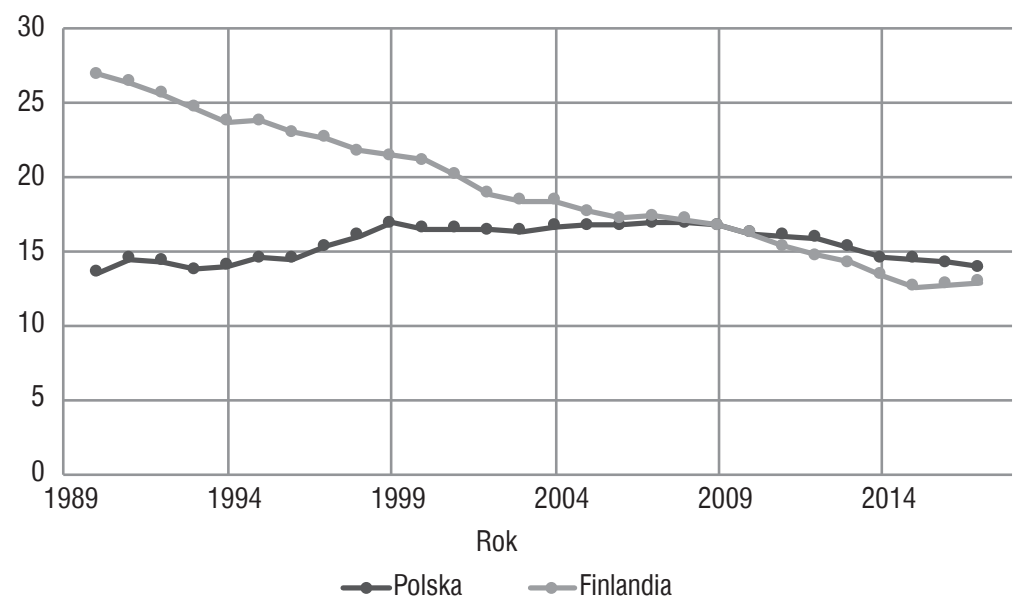

Źródło: opracowanie własne na podstawie danych z bazy Global Burden of Disease (2018).

3 O tym jak niepełna jest wiedza na temat przyczyn zgonów śmiercią samobójczą w Polsce, może świadczyć fakt, że w 2020 r. na 5165 samobójstw zakończonych zgonem powodu samobójstwa nie ustalono w 57\% przypadków. Na wykresie wykorzystano dane porównawcze pochodzące z bazy Global Burden of Disease opierającej się na danych gromadzonych przez Światową Organizację Zdrowia na podstawie oficjalnych statystyk narodowych. O aktualnych wątpliwościach i kontrowersjach dotyczących gromadzenia danych nt. liczby samobójstw w Polsce i różnicach między oficjalnymi statystykami a danymi policyjnymi można przeczytać w Gawliński, Sołtyszewski, Wiergowski (2020). 
Gdy przyjrzymy się policyjnym statystykom dotyczącym zachowań samobójczych zakończonych zgonem w Polsce (ok. 85\% samobójstw w 2020 r. popełnionych było przez mężczyzn, najczęściej stosowaną metodą było powieszenie - 79\%, a najczęstszym powodem zaburzenie psychiczne - 20\%), możemy stworzyć sobie pewien ogólny obraz zjawiska i osób podejmujących taką decyzję, jednak wymieniane powody są zaledwie prawdopodobne (zazwyczaj tak zinterpretowane przez osoby z zewnątrz), znacznie częściej pozostają nieokreślone (Komenda Główna Policji, 2021).

Wspomniane statystyki wskazują na aktualność „polskiego problemu” opisywanego już w 2012 r. na łamach brytyjskiego czasopisma specjalizującego się w epidemiologii i zdrowiu publicznym w artykule pod znaczącym tytułem: Forty years of increasing suicide mortality in Poland: Undercounting amidst a hanging epidemic? (Czterdzieści lat rosnącej śmiertelności samobójczej w Polsce: niedoszacowanie w obliczu wiszącej epidemii?). Praca ta wskazywała nie tylko na możliwe znaczne niedoszacowanie skali zjawiska i trwałość wzorów zachowań suicydalnych, ale również na destrukcyjny wpływ braku rozwiązań systemowych w zakresie prewencji (Hoffer et al., 2012). Wydaje się, że diagnoza austriackich badaczy po 10 latach tylko zyskała na aktualności, mimo zwiększonej obecności problematyki samobójstw w dyskursie publicznym (Adamczyk, 2021; Witkowska, 2021).

Niniejszy artykuł ma na celu prezentację fińskiego modelu zapobiegania samobójstwom jako skutecznego działania w zakresie polityki publicznej oraz rozważenie możliwości zastosowania podobnych rozwiązań w polskich realiach, a przynajmniej zainspirowania się nimi w celu zmniejszenia wskaźnika zachowań samobójczych w kraju.

\section{Samobójstwo - fińska specjalność?}

W latach 80. i 90. XX w. Finlandię wymieniano powszechnie jako kraj o szczególnie wysokich wskaźnikach samobójstw, uznając jednocześnie przyczyny wysokiej stopy aktów samobójczych za najbardziej zagadkowe. W odniesieniu do innych państw formułowano pewne uogólniające wyjaśnienia oparte na czynnikach kulturowych. Do dużej liczby samobójstw w krajach bloku wschodniego (Węgry) i obszaru postsowieckiego (Rosja, Litwa) miały się przyczyniać niskiej jakości systemy wsparcia dla osób dotkniętych zaburzeniami oraz traumatyczne doświadczenia związane z gwałtownymi przemianami społeczno-gospodarczymi po upadku komunizmu i rozpadzie Związku Radzieckiego. W przypadku Chin i Japonii zwracano z kolei uwagę na wpływ religii konfucjańskiej na zachowania jednostek (Goldsmith et al., 2001: 196-197). 
Skłonność do samobójstw stała się trwałym elementem fińskiego stereotypu i autostereotypu. Jeszcze w 2020 r. Sidz (2020: 168) w książce reporterskiej o Finlandii powtórzyła argument o tej szczególnej skłonności, cytując na potwierdzenie fragment powieści Paasilinny z 1990 r.: „Największym wrogiem Finów jest przygnębienie, smutny nastrój, bezdenna apatia. Wiszące nad nieszczęśliwcami ciężkie myśli po tysiącach lat panowania tak ich sobie podporządkowały, że dusza tego narodu stała się mroczna i poważna. Macki smutku mają ogromną siłę i wielu Finów uważa, że jedynie śmierć może ich wyrwać z przygnębienia. Czarne myśli wydają się im gorszym nieprzyjacielem niż Związek Radziecki” (Paasilinna, 2007: 5) ${ }^{4}$.

Gdy Paasilinna pisał swą książkę, zatytułowaną Fantastyczne samobójstwo zbiorowe, postrzeganie Finów jako nacji wyjątkowo skłonnej do samobójstw było całkowicie uzasadnione. To był rok o największej w historii zarejestrowanej ich liczbie, która przekroczyła 1500 (27 na 100 tys. mieszkańców). Jednak liczba samobójstw w Finlandii przez następne 25 lat stale i proporcjonalnie spadała.

\section{Diagnoza przed działaniem, czyli polityka publiczna po fińsku}

Przystępując do omówienia fińskiej strategii przeciwdziałania samobójstwom, warto dostrzec, że wiele kwestii dotyczących samobójstw w ostatnich dekadach stało się w Finlandii przedmiotem licznych badań naukowych prowadzonych w ramach różnych dyscyplin naukowych. To czynnik znacząco różnicujący kontekst polski i fiński. W trzech najważniejszych międzynarodowych, interdyscyplinarnych czasopismach naukowych zajmujących się suicydologią (The Journal of Crisis Intervention and Suicide Prevention; Archives of Suicide Research; Suicide and Life-Threatening Behavior) można znaleźć dziesiątki artykułów poświęconych fińskiemu przypadkowi i autorstwa fińskich badaczy. Jednocześnie tekstów analizujących samobójstwa i próby samobójcze w Polsce nie znajdziemy w nich wcale, nieliczne teksty autorstwa lub współautorstwa polskich badaczy i badaczek poświęcone są wątkom historycznym, np. samobójstwom w gułagach i obozach koncentracyjnych (np. Ryn, 1986; Krysinska, Lester, 2008) lub obrazom samobójstw w serialach telewizyjnych (Andriessen, Krysinska, 2020).

4 Słowa te padają na początku książki. W kolejnych akapitach Paasilinna prezentuje malowniczy opis Juhannusa (czerwcowego święta równonocy obchodzonego przez Finów na łonie natury, przy ogniskach, z rodziną i przyjaciółmi) jako podlanej znaczną ilością alkoholu dorocznej bitwy Finów ze smutkiem i depresją. 
Z kolei analiza bibliometryczna dorobku naukowego w dziedzinie suicydologii opublikowanego we wszystkich indeksowanych w bazie Web of Science międzynarodowych periodykach naukowych w latach 1989-2018 (uwzględniającego 41276 publikacji) wskazuje, że fińscy badacze opublikowali w tym czasie 501 prac na ten temat (Astraud, Bridge, Jollant, 2021). Kilkoro z nich umieszczono również wśród stu najczęściej publikujących i najczęściej cytowanych autorów. W rankingu tym znalazły się psycholog i psychiatra polskiego pochodzenia Danuta Wasserman, która od początku lat 70. XX w. pracuje w szwedzkich placówkach naukowych, oraz afiliowana w australijskich uniwersytetach Karolina Krysińska, w zestawieniu „nie liczą się” więc one jako badaczki polskie. Louis-Paul Astraud, współautor wspomnianej analizy bibliometrycznej, w bezpośredniej komunikacji e-mailowej przekazał informację, nieobecną w opublikowanej wersji artykułu, że w objętej analizą próbie znalazło się tylko (biorąc pod uwagę, że Polska jest krajem ośmiokrotnie ludniejszym od Finlandii) 245 artykułów autorstwa lub współautorstwa naukowców afiliowanych w polskich jednostkach. Oczywiście widoczna dysproporcja nie jest wynikiem (a na pewno nie wyłącznie) braku zainteresowania polskich naukowców tematem. Przeświadczenie o konieczności zapewnienia naukowej diagnozy sytuacji zanim wprowadzi się jakiekolwiek rozwiązania instytucjonalne, jest jednak powszechne i obecne w fińskiej praktyce budowania i funkcjonowania struktur państwa od początku ich suwerennego istnienia, a prowadzenie niezależnych badań naukowych i ewaluacji jest od wielu lat elementem modus operandi funkcjonowania polityki publicznej (zob. Woźniak, 2021). Finlandia przez wiele lat była jednym z niewielu państw Unii Europejskiej finansującym naukę na poziomie 3,5\% PKB rocznie (wyższym niż rekomendowane przez Komisję Europejską jako cel strategii lizbońskiej 3\%). W konsekwencji kryzysu lat 2008-2009 oraz polityki cięć budżetowych rządu premiera Juhy Sipili w latach 2015-2019 nakłady te obniżyły się - w 2018 r. wyniosły ok. 2,8\%. Chociaż $\mathrm{w}$ analogicznym okresie wydatki na badania i rozwój w Polsce wzrosły dwukrotnie, to ich pułap był na tyle niski (od 0,6 do 1,2\% PKB), że wciąż pozostawały zaledwie na poziomie około połowy średniej dla całej Unii Europejskiej (Eurostat, 2020)5. Fińscy naukowcy mają świadomość wyjątkowej sytuacji zarówno pod względem środków na badania, jak i uprzywilejowanej pozycji pod względem dostępu do danych i możliwości realizowania projektów. Przykładem wyjątkowego na globalną skalę projektu naukowego był właśnie program badawczy, który doprowadził do opracowania pierwszej na świecie strategii przeciwdziałania samobójstwom.

5 O znaczeniu sektora badawczo-rozwojowego w Finlandii świadczy również fakt, że zatrudnia on najwyższy wśród krajów OECD odsetek badaczy w populacji (Woźniak, 2021; Knight, Routti, 2012: 78). 


\section{Samobójstwo jako problem do rozwiązania}

W latach 1986-1996 Finlandia stała się pierwszym krajem na świecie, który wdrożył rekomendacje WHO zawarte w dokumencie Health for All by the Year 2000 opublikowanym w 1981 r., podejmując prace nad narodowym programem zapobiegania samobójstwom. Schyłek lat 70. XX w. to moment, gdy fińskie polityczne elity uznały problem samobójstw za jedno z istotnych wyzwań makrospołecznych stojących przed państwem, które podejmowało właśnie próbę zasadniczej reformy własnej polityki publicznej, w tym gospodarczej, stawiając na innowacyjność. Jednym z kluczowych elementów fińskiej modernizacji była inwestycja w kapitał ludzki, możliwość realizacji potencjału kolejnych kohort ludności, m.in. poprzez edukację, którą rozwijano na wszystkich szczeblach, rozbudowując również instytucje kształcenia ustawicznego. $Z$ tej perspektywy wysoka liczba samobójstw oraz prób samobójczych stanowiła marnotrawstwo potencjału fińskiego społeczeństwa.

Erkki Isometsä, profesor psychiatrii pełniący w 2021 r. funkcję przewodniczącego Fińskiego Towarzystwa Psychiatrycznego, jeden z najczęściej cytowanych fińskich suicydologów, w latach 80 . XX w. jako młody badacz uczestniczył w owych badaniach i przygotowywaniu strategii walki z samobójstwami. W wywiadzie przeprowadzonym w 2021 r. przez autorów niniejszego artykułu zwrócił uwagę na rzadko wspominany indywidualny czynnik, który mógł mieć znaczenie dla wsparcia politycznego w uznaniu tej strategii za priorytet w polityce zdrowotnej. Było nim osobiste doświadczenie Eevy Kuuskoski kierującej ministerstwem zdrowia, której małżonek, Juha Vikatmaa (również polityk), kilka lat wcześniej w wieku 33 lat popełnił samobójstwo. Z kolei Sami Pirkola, profesor psychiatrii będący współtwórcą nowej, opracowanej w 2020 r. Narodowej Strategii Zdrowia Psychicznego w wywiadzie mówił: „Jeśli mówimy o [dotyczącym samobójstw] tabu i stygmatyzacji, myślę, że sytuacja była podobna jak w innych krajach. Samobójstwo nigdy nie było łatwym tematem do dyskusji, ale mass media donosiły o przykładach dramatycznych samobójstw, i tu, w Finlandii, chyba zaczęliśmy o nich dyskutować wcześniej niż gdzie indziej”.

Najpierw powstała komisja parlamentarna, której zadaniem było opracowanie założeń reformy polityki w zakresie zdrowia publicznego, a na początku lat 80 . XX w. minister spraw społecznych i zdrowia autoryzował wprowadzenie strategii mającej dwa skwantyfikowane cele: zahamowanie wzrostu liczby samobójstw, a następnie zmniejszenie wskaźnika samobójstw o 20\% do 1996 r. Działanie podzielono na dwie fazy - faza planowania trwała w latach 1986-1991 i obejmowała szeroko zakrojone badania naukowe, natomiast faza implementacji miała miejsce w latach 1992-1996 i oparta była na rekomendacjach opracowanych na podstawie oryginalnych badań własnych. Program koordynowany był przez National Public Health Institute (KTL) 
oraz National Research and Development Centre for Welfare and Health (STAKES). Wprowadzenie ogólnokrajowej strategii przeciwdziałania samobójstwom „National Suicide Prevention Project" (dalej NSPP) poprzedzone było dwuletnim badaniem, które miało za zadanie uzupełnić nieliczne podstawowe dane, jakie na temat samobójstw gromadzono w statystykach publicznych. W latach 1987-1988 grupa 450 naukowców z różnych dziedzin przeprowadziła największe w historii Finlandii interdyscyplinarne badania na temat samobójstw (Myllykangas, 2018: 165).

Ich kluczowym elementem było przeprowadzone w latach 1987-1988 nowatorskie na skalę globalną badanie nazwane "psychologiczną autopsją samobójstw” (psychological suicide autopsy). Projekty badawcze tego typu prowadzono od lat 50. XX w. przede wszystkim w Stanach Zjednoczonych, jednak obejmowały one do tej pory najczęściej analizę maksymalnie stu kilkudziesięciu przypadków samobójstw popełnionych na ograniczonym terytorium (Isometsä, 2001: 380-381; Cavanagh et al., 2003). Badanie fińskie po raz pierwszy dotyczyło wyczerpującej próby, obejmującej wszystkie przypadki w populacji. Badacze przeprowadzili wówczas bardzo szczegółową analizę każdego z 1397 przypadków samobójstw odnotowanych w kraju w ciągu roku pomiędzy 1 kwietnia 1987 r. a 31 marca 1988 r. ${ }^{6}$.

Wywiady prowadziło 245 osób należących do personelu medycznego (najczęściej psychologów, także lekarzy, pielęgniarek psychiatrycznych lub pracowników socjalnych). W badaniu rozmawiano $\mathrm{z}$ rodzinami zmarłych przy użyciu ustrukturyzowanego kwestionariusza obejmującego 234 itemy dotyczące ich codzienności, stylu życia, relacji rodzinnych, doświadczeń z instytucjami pomocowymi, zdarzeń poprzedzających popełnienie samobójstwa oraz psychospołecznych czynników wpływających na sytuację osobistą. Tego typu wywiady przeprowadzono z rodzinami $83 \%$ (1155) ofiar samobójstw zakończonych zgonem. W przypadku 43,8\% samobójstw (612) udało się dotrzeć do lekarzy lub terapeutów zajmujących się osobami, które popełniły samobójstwo, w celu przeprowadzenia wywiadów na temat ich stanu zdrowia i terapii. W 61,6\% przypadków (860) udało się porozmawiać z ostatnią osobą lub osobami z instytucji pomocowych, z którymi kontaktowali się przyszli samobójcy (w celu sprawdzenia, czy intencja samobójcza była w jakikolwiek sposób komunikowana) (Isometsä et al., 1995). Korzystano z danych o denatach pochodzących z aktów zgonów, raportów policyjnych, wyników autopsji, listów samobójczych i innych

6 W ramach projektu przeprowadzono również analizę 139 przypadków zgonów o nieustalonej przyczynie. Wyniki pozwoliły badaczom na sformułowanie ostrożnego wniosku, że większość z nich mogła być przypadkami śmierci samobójczych (Ohberg, Lönnqvist 1998: 217). Szczegółowej analizie poddano również wszystkie podkategorie samobójstw, niezależnie od ich liczebności (np. 26 przypadków samobójstw popełnionych w szpitalach, Suominen, et al. 2002), wszystkie wyniki publikowano w uznanych czasopismach naukowych. 
źródeł (Isometsä, 2001: 380-382). Okazało się, że spośród poddanych „autopsji” samobójców 93\% miało problemy psychiczne (najczęściej epizody depresji - 59\%, zaburzenia osobowości - 31\%), 43\% nadużywało albo było uzależnionych od alkoholu, a 88\% miało przynajmniej jedno poważne schorzenie somatyczne (Henrikson et al., 1993: 936-937).

Powstała w ten sposób baza danych pozwoliła w znaczący sposób uzupełnić wiedzę na temat fenomenu samobójstw. Rozwijająca się od lat 60. XX w. suicydologia zmieniła wcześniejsze postrzeganie samobójstw - zaczęto je rozpatrywać w perspektywie interdyscyplinarnej, łączącej aspekty psychiatrii, psychologii i nauk społecznych. Skomplikowana rama pojęciowo-analityczna okazała się niezbędna do zrozumienia zjawiska i przeciwdziałania mu. Interdyscyplinarne podejście uznano za konieczne nie tylko w przypadku badania samobójstw, ale i profesjonalnego, opartego na eksperckiej wiedzy diagnozowania zagrożenia samobójstwem na poziomie jednostkowym.

Za jeden z kluczowych czynników wysokiej stopy samobójstw uznano słabość diagnostyczną systemu opieki zdrowotnej w zakresie chorób psychicznych oraz niewłaściwe postępowanie terapeutyczne. Wczesne rozpoznanie ryzyka wystąpienia zachowania samobójczego lub symptomów depresji oraz dostrzeżenie potencjału autodestrukcyjnego jest warunkiem wdrożenia „wczesnej interwencji”. Jednym z rezultatów pracy ekspertów w ramach NSPP było więc opracowanie szerokiej listy rekomendacji, której adresatami byli przedstawiciele wielu rozmaitych profesji zarówno medycznych (lekarze wszystkich specjalności, pielęgniarki), jak i z grona szeroko rozumianych służb społecznych (nauczyciele, pracownicy socjalni, psychologowie szkolni, kuratorzy). Fińskie Towarzystwo Zdrowia Psychicznego (Finnish Mental Health Association) odgrywało kluczową rolę w działaniach profilaktycznych, odpowiadając m.in. za doradztwo i szkolenia personelu różnych instytucji w zakresie wspierania osób w kryzysie psychicznym/emocjonalnym. Z drugiej strony, jak opowiada w wywiadzie Pirkola, okazało się wówczas, że zdecentralizowany na początku lat 90 . XX w. system organizacji opieki zdrowotnej nie przyczyniał się do zapewnienia wsparcia dobrej jakości, szczególnie w obliczu recesji lat 1991-1993, gdy samorządy zmuszone były do szukania oszczędności w każdym obszarze swoich działań. Rozproszenie nie sprzyjało jakości i dostępności, co skutkowało działaniami integrującymi instytucjonalną pomoc, przy zapewnieniu szkoleń dla osób pierwszego kontaktu w systemie opieki. Umiejętność nawiązania przez nie kontaktu z osobami w kryzysie okazała się kluczowa, wraz z wiedzą umożliwiającą szybkie skierowanie osób potrzebujących specjalistycznej pomocy do właściwych placówek.

Oprócz szkoleń opracowano wiele materiałów szkoleniowych i poradników, których odbiorcami byli zarówno pracownicy instytucji, jak i osoby w kryzysie psychicznym, potencjalnie zagrożone aktami autoagresji. To te osoby uznano za najważniejszą 
grupę odbiorców kolejnego komponentu programu, czyli kampanii informacyjnej mającej za zadanie wskazać potrzebującym, gdzie szukać pomocy. Jednym z celów programu było także doprowadzenie do zmiany sposobu opisywania zjawiska samobójstwa $\mathrm{w}$ mass mediach, szkolenia $\mathrm{z}$ wiedzy na temat samobójstw organizowano więc także dla dziennikarzy czy twórców popkultury, których zachęcano do pogłębiania wiedzy na temat zdrowia psychicznego.

Wśród czynników „miękkich”, które przynajmniej pośrednio można wiązać z realizacją szeroko relacjonowanej w mediach strategii zwalczania samobójstw, jest proces stopniowej detabuizacji zarówno samego zjawiska samobójstwa, jak i problemów psychicznych. Isometsä we wspomnianym wywiadzie mówił, że w latach 80. i 90. często diagnozował depresję u pacjentów płci męskiej, którzy swoim bliskim i współpracownikom relacjonowali, że cierpią na „wypalenie zawodowe”, w ich mniemaniu obarczone mniejszym ryzykiem stygmatyzacji niż niepasująca do fińskiej, kulturowo ugruntowanej koncepcji męskości depresja. W latach 90. pojawiło się w fińskim dyskursie wiele przekazów autorstwa osób publicznych, także celebrytów, które opowiadały o swoich doświadczeniach z diagnozą i leczeniem zaburzeń psychicznych. Powstało siedem kluczowych rekomendacji dotyczących zasad skutecznego wspierania osób zagrożonych samobójstwami, sformułowanych na podstawie wyników badań:

1. Zapewnić wsparcie i opiekę dla osób po próbie samobójczej.

2. Poprawić jakość terapii dostępnej pacjentom z ciężkim przebiegiem depresji.

3. Edukować w zakresie ryzyka związanego $\mathrm{z}$ traktowaniem alkoholu jako narzędzia pomagającego rozwiązywać życiowe problemy.

4. Zwiększyć społeczne i psychologiczne wsparcie w trakcie leczenia chorób psychicznych.

5. Promować dostępność i edukować w zakresie profesjonalnego wsparcia w kryzysach życiowych.

6. Zapobiegać alienacji młodych obywateli. Pomóc im w kreowaniu możliwości, warunków i sposobów radzenia sobie z życiem oraz w zdobywaniu satysfakcjonujących doświadczeń.

7. Wzmacniać w ludziach pozytywne nastawienie do życia, a także ich pewność siebie, wytrwałość i gotowość do udzielania wzajemnego wsparcia (Partonen, 2016).

\section{Strategia oparta na dowodach naukowych}

Fińska strategia zapobiegania samobójstwom jest dobrym przykładem polityki publicznej opartej na dowodach naukowych (evidence-based policy). W latach 1991-2011 przeprowadzono studium, w trakcie którego monitorowano pełną populację 
fińskich pacjentów hospitalizowanych w ciągu tych dwóch dekad z rozpoznaniem depresji. W bazie danych zintegrowano informacje $\mathrm{z}$ rejestrów szpitalnych oraz urzędów statystycznych dotyczące tych pacjentów, a następnie aż do 2014 r. (lub do ich śmierci, jeśli nastąpiła wcześniej) monitorowano przebieg ich życia. Celem badania było m.in. zdiagnozowanie skuteczności różnych terapii. Jego niezwykła wartość diagnostyczna polega na wieloletnim stałym badaniu bardzo licznej populacji (w próbie znalazło się 56826 pacjentów) (Aaltonen et al., 2018a; 2018b). Przeprowadzenie tak szeroko zakrojonych badań longitudinalnych lub kohortowych wymaga jednak znacznych nakładów finansowych. Ze względu na powtarzanie kolejnych fal badania lub wielokrotne docieranie do badanych wymagają one stałego finansowania przez wiele lat.

Fińscy badacze (np. Isometsä we wspomnianym wywiadzie) przyznają, że przez długi czas mieli komfortową sytuację pod względem warunków organizacyjnych do prowadzenia tego typu badań. Nie tylko ze względu na hojne finansowanie nauki $\mathrm{z}$ budżetu, ale również przez fakt, że instytucje publiczne były zobowiązane do przekazywania badaczom danych dotyczących ich podopiecznych, pacjentów i klientów. Ten typ wykorzystywania danych osobowych nie był przedmiotem kontrowersji ani dyskusji, uznawano naukową diagnozę za wyższe dobro niż prawo obywateli do dysponowania swoimi danymi. Isometsä przyznał, że wprowadzona w 2016 r. unijna regulacja General Data Protection Regulation (znana w Polsce jako RODO) znacznie utrudnia prowadzenie tego typu badań.

\section{Programy przeciwdziałania samobójstwom - przykłady}

Jest wiele przykładów działań praktycznych wdrażanych w Finlandii, których explicite deklarowanym celem lub jednym z możliwych oczekiwanych skutków jest wzmocnienie systemu opieki nad pacjentami (lub potencjalnymi pacjentami) z zaburzeniami psychicznymi, prewencja zachowań suicydalnych, zwiększenie świadomości istnienia problemu oraz przełamywanie wciąż istniejących tabu. Wszystkie oparte są na diagnozie naukowej, często zaś umocowanie znajdują w systemie polityki publicznej. Przykładem może być program „Time Out! Getting Life Back on Track", wykorzystujący instytucję poboru do obligatoryjnej służby wojskowej w celu prowadzenia diagnozy kondycji psychicznej poborowych. Należą oni do kohorty wieku (18-24 lata), w której samobójstwo jest najczęstszą przyczyną śmierci. Szczególną wagę przywiązuje się do monitorowania zdrowia psychicznego tych 20\% mężczyzn z każdego rocznika, którzy z różnych powodów nie trafiają do armii, z badań wynika bowiem, że to oni są szczególnie narażeni na występowanie 
zaburzeń (Appelqvist-Schmidlechner, 2011). Profilaktyka tego typu jest jednak niemożliwa do zaimplementowania w krajach, w których nie ma uniwersalnego poboru.

Część z działań opracowano w trakcie funkcjonowania w/w strategii, inne były nią jedynie inspirowane. Niektóre z nich mają charakter wszechstronnych, długotrwałych, ogólnokrajowych projektów wymagających znacznych nakładów finansowych i angażujących wiele instytucji. Poniżej przywołano dwa przykłady fińskich programów profilaktycznych, których konstrukcja i grupa docelowa znacznie się od siebie różnią, a które okazały się słusznie podjętymi działaniami ilustrującymi konieczność korzystania z rozbudowanej strategii prewencji.

\section{KiVa - walka z przemocą rówieśniczą}

KiVa (akronim od słów: Kiusaamista Vastaan, czyli „przeciw przemocy rówieśniczej””, wykorzystujący grę słów - kiva w języku fińskim oznacza również „miły”) to program mający na celu wypracowanie i wdrożenie kroków na rzecz przeciwdziałania zjawisku przemocy rówieśniczej. Jest to przykład polityki publicznej zaprojektowanej i wdrożonej w odpowiedzi na zidentyfikowany w badaniach naukowych problem społeczny. Wprawdzie fiński system edukacji od początku XXI w. cieszył się globalną renomą ze względu na świetne wyniki fińskich uczniów w badaniach PISA, jednak kilka lat później w raporcie afiliowanego przy UNICEF centrum badawczego Innocenti (2007) wskazano, że ze wszystkich 34 objętych badaniem państw to w Finlandii zanotowano najniższy odsetek uczniów deklarujących, że lubią chodzić do szkoły. W pogłębionych badaniach okazało się, że ważną przyczyną jest tu doświadczanie przemocy rówieśniczej. Opracowanie narodowego programu przeciwdziałania temu zjawisku zlecono interdyscyplinarnemu zespołowi specjalistów od edukacji z Uniwersytetu w Turku pod kierownictwem Christiny Salmivalli. W efekcie trzyletniego projektu stworzono oraz wdrożono testowo program na poziomie dziewięcioletnich szkół podstawowych (Salmivalli et al., 2013: 81). Program ma charakter holistyczny, wymaga zaangażowania i współpracy kadry dydaktycznej, uczniów i rodziców. KiVa w założeniu ma stać się elementem codzienności szkolnej uczniów, a nie działalnością reaktywną. Drugim komponentem KiVa jest jednak opracowany w ramach projektu scenariusz działań, które należy wdrażać właśnie w sytuacji, gdy przypadek przemocy rówieśniczej w szkole został już zidentyfikowany (Kärnä et al., 2013). Jest to ogólnokrajowy program spełniający kryteria polityki publicznej opartej na dowodach

\footnotetext{
$7 \mathrm{~W}$ anglojęzycznych publikacjach na temat programu KiVa mowa o przeciwdziałaniu zjawisku „bullying-u”. Ponieważ nie ma jednoznacznego wzoru tłumaczenia tego terminu w języku polskim, uznano, że najadekwatniejsze w tym kontekście będzie posługiwanie się pojęciem „przemoc rówieśnicza”.
} 
(evidence-based policy) zakładający, że kluczową rolę w przemocy rówieśniczej odgrywają rówieśnicy - świadkowie (peer bystanders), którzy mogą wzmacniać społeczną gratyfikację, jaką znęcający się uczniowie czerpią ze swoich działań. Materiały szkoleniowe dla szkolnej kadry koncentrują się więc na umiejętności analizy mechanizmów i procesów psychologicznych zachodzących w grupie, oferując nauczycielom jasno sformułowane sugestie. Uniwersalne interwencje organizowane $w$ ramach programu KiVa wdrażane są na podstawie formułowanych w ramach badań zaleceń. Rozliczne ewaluacje projektu, których wyniki były publikowane w czołowych czasopismach naukowych (bibliografia artykułów naukowych na temat projektu liczy ponad 100 międzynarodowych publikacji), wskazują, iż KiVa zwiększyła odsetek uczniów deklarujących, że lubią swoją szkołę, miała też wpływ na wzrost motywacji do nauki, a także poprawę wyników szkolnych większości uczniów, w porównaniu z uczniami ze szkół kontrolnych, w których programu nie wprowadzono. Program stał się kolejnym fińskim „towarem eksportowym”, który za opłatą licencyjną i pod nadzorem specjalistów z Turku wdrażany jest (na różną skalę) w 11 krajach europejskich, a także w Nowej Zelandii, Chile, Argentynie i Meksyku (KiVa, 2021).

\section{Męska rozrywka, męska przyjaźń, męskie problemy}

Niektóre interwencje opierają się na diagnozie pokazującej istniejący problem lub wskazującej potencjalne zagrożenie w odniesieniu do konkretnego regionu lub specyficznej grupy społecznej. I tak np. w regionie Kainuu zdiagnozowano w pierwszej dekadzie XXI w. znacznie częstsze występowanie samobójstw wśród dorosłych mężczyzn, niż wynosiła średnia dla całego kraju. Badania wskazały, że najczęstszym narzędziem wykorzystywanym w ponad połowie zamachów samobójczych zakończonych zgonem jest legalnie posiadana broń myśliwska. Kainuu to jeden z 19 regionów Finlandii, zamieszkany przez około 70 tys. mieszkańców i pokryty głównie niezamieszkałym lasem (tajgą). To tradycyjny rejon myśliwski, w którym broń jest ogólnodostępna, a polowania stanowią jeden z najpowszechniejszych sposobów spędzania wolnego czasu, będący też dla wielu mieszkańców regionu dodatkowym źródłem dochodu.

W 2011 r. lokalna administracja samorządowa powołała interdyscyplinarną grupę roboczą, której zadaniem miało być opracowanie programu prewencyjnego. W jej skład weszli przedstawiciele samorządowych władz lokalnych, eksperci związani z Uniwersytetem Nauk Stosowanych w Kajaani (jedyną w regionie zawodową szkołą wyższą), przedstawiciele policji, wydziału zdrowia i spraw społecznych, lokalna organizacja łowiecka oraz specjaliści ds. zdrowia psychicznego. Wypracowany wspólnie model działania nazwano później modelem Hyvä Mehtäkaveri (co można 
przetłumaczyć jako „dobry łowczy towarzysz”). Opierał się na dobrze ugruntowanym przeświadczeniu, że bliskie a niespokrewnione osoby (rówieśnicy, przyjaciele, znajomi) mogą być ważnym i adekwatnym źródłem wsparcia w kryzysie psychicznym. Projekt miał na celu przeszkolenie myśliwych polujących w regionie Kainuu $\mathrm{w}$ zakresie umiejętności miękkich, przede wszystkim nawiązywania i prowadzenia rozmowy o problemach (w tym o intymnych problemach osobistych czy rodzinnych) oraz umiejętności dostrzegania symptomów depresji i głębokiego stresu. Celem projektu było również zdestygmatyzowanie depresji w środowisku, w którym szczególnie zakorzeniony jest model tradycyjnej męskości (zgodny ze stereotypem fińskiego mężczyzny), który o swoich problemach najczęściej milczy. W pierwszej fazie przeprowadzono 120 wywiadów na temat osobistych doświadczeń członków myśliwskiej społeczności, co pozwoliło dopasować zawartość szkoleń do ich potrzeb, możliwości i oczekiwań. Zainteresowanie programem przeszło oczekiwania twórców projektu - na pierwsze spotkanie w miejscowości Suomussalmi przyszło 30 myśliwych z okolicy, a spotkania organizowane w kolejnych okręgach budziły podobny odzew. $\mathrm{Na}$ ewaluacyjnym spotkaniu zorganizowanym po roku od pierwszych szkoleń wszyscy uczestnicy twierdzili, że w tym czasie stosowali wiedzę wyniesioną z programu. Ewaluacja projektu pozwoliła wykazać, że spełnia on swoje zadanie w zakresie promocji zdrowia psychicznego i holistycznego wsparcia kryzysowego. Jako że uznano go za „dobrą praktykę", od 2015 r. trwa jego wdrażanie w innych, tradycyjnie myśliwskich regionach Finlandii (Lukkari, Rautiainen, 2013; Nordling, 2014).

KiVa i Hyvä Mehtäkaveri to tylko dwa przykłady programów mających na celu wsparcie instytucjonalne grup szczególnie narażonych na psychologicznie destrukcyjne konsekwencje relacji międzyludzkich (lub ich braku). Oba programy oparto na naukowej diagnozie i dostosowano do fińskich realiów, jednak łatwo sobie wyobrazić, że podobne działania można wdrożyć w innych krajach - tak na poziomie ogólnokrajowym, jak regionalnym czy też skoncentrowane na specyficznej grupie docelowej. Nie ma jednak wątpliwości, że niezbędna jest do tego rzetelna, oparta na naukowych dowodach wiedza na temat skali i specyfiki zjawiska, a także stworzenie możliwie szerokiej koalicji społecznych aktorów z instytucjami oraz politycznym wsparciem gwarantującym finansowanie i stabilność realizacji działań.

\section{Co działa i dlaczego? Ewaluacja wyników}

Zgodnie z wewnętrznymi i zewnętrznymi badaniami ewaluacyjnymi fiński program zapobiegania samobójstwom okazał się sukcesem. Śmiertelność zmniejszyła się o $11 \%$ w czasie trwania programu i spadała dalej po jego zakończeniu (Isometsä, 
2017). Szeroko zakrojonych badań porównawczych na temat skuteczności narodowych programów prewencji samobójstw jest niewiele. W jednym z nielicznych (Lewitzka et al., 2019) wzięto pod uwagę programy tego typu opracowane w Australii, Finlandii, Szwecji i Norwegii, dobierając te kraje ze względu na znaczną ilość szczegółowych i wiarygodnych danych, co pozwala przeprowadzić rzetelną komparatystykę. Badacze wskazali, że wspólną cechą wypracowanych programów jest szerokie formułowanie celów. Mają one wspomagać identyfikowanie szczególnie narażonych na zachowania samobójcze grup i kategorii społecznych, wzmacniać jakość diagnostyki i opieki nad pacjentami lub potencjalnymi pacjentami z tendencjami do zachowań autodestrukcyjnych, poprawiać monitorowanie i wspierać badania suicydologiczne oraz przeciwdziałać tabuizacji tego zjawiska i stygmatyzacji dotkniętych nim osób i grup. W tym celu wykorzystywano rekomendacje i zalecenia Światowej Organizacji Zdrowia (WHO) oraz Międzynarodowej Organizacji na rzecz Zapobiegania Samobójstwom (International Association for Suicide Prevention - IASP).

Isometsä podkreśla, że określenie wpływu poszczególnych czynników na redukcję zachowań samobójczych nie jest możliwe. Wskazuje jednak na korelację tego trendu ze zwiększającą się częstotliwością przepisywania leków na depresję, coraz częściej diagnozowanym w ten sposób pacjentom (2017). W wywiadzie zaś komentując te dane, wiąże je z pojawianiem się nowych generacji leków antydepresyjnych, bezpieczniejszych i trudniejszych do przedawkowania, co ośmieliło lekarzy do częstszego korzystania $\mathrm{z}$ tej formy farmakoterapii.

\section{Dyskusja}

Omówione w artykule fińskie „dobre praktyki” zapobiegają samobójstwom poprzez koncentrację na prewencji, czyli działaniach zmniejszających ryzyko kryzysu, lub na nauce konstruktywnego radzenia sobie z nim. Program NSPP był też inspiracją przy opracowywaniu nowej Narodowej Strategii Zdrowia Psychicznego 2020-2030 (2020: 17-37), w której prewencja zachowań suicydalnych jest jednym z zadań realizowanych $\mathrm{w}$ ramach wszystkich pięciu filarów strategii. Są to:

1) zdrowie psychiczne jako kapitał (zasób),

2) zdrowie psychiczne dzieci i młodzieży,

3) zdrowie psychiczne jako prawo (obywatelskie),

4) dostępne i adekwatne do potrzeb usługi w zakresie zdrowia psychicznego,

5) zarządzanie zdrowiem psychicznym.

Warto się zastanowić, w jaki sposób rozwiązania inspirowane fińskimi można byłoby wdrożyć w Polsce, ponieważ jak opisywał Zwoliński (2013: 254) w społeczeństwie 
zazwyczaj tworzone są grupy reaktywne zamiast proaktywnych, a więc zamiast przewidywać i wzmacniać - „leczy się”, tj. reaguje na zaobserwowany skutek. Sytuacja wygląda podobnie $\mathrm{w}$ działaniach instytucjonalnych i w rozwiązaniach polityki publicznej.

Wydaje się, że pierwszą różnicą między podejściem polskim a fińskim do tematu samobójstw jest skala eksploracji zjawiska. Programy badawcze psychologicznej autopsji samobójstw są wymagające i kosztowne, jednak wydają się wyjątkowo skutecznymi narzędziami do przeprowadzenia całościowej diagnozy dotyczącej czynników skłaniających do zachowań samobójczych w konkretnym kontekście społeczno-kulturowym. Istnieją wprawdzie prace wskazujące na niedostatki metodologiczne tych projektów (Hjelmeland et al., 2012), niemniej takie wątpliwości będą się pojawiać w przypadku wszystkich interdyscyplinarnych projektów badawczych, w których współpracować muszą specjaliści z tak różnych pod względem paradygmatów metodologicznych dziedzin jak psychiatria, epidemiologia, psychologia czy socjologia.

Wyniki badań przeprowadzonych w innych okolicznościach społeczno-kulturowych trudno bowiem uogólniać. Specyficzne czynniki związane choćby z funkcjonowaniem krajowych systemów służby zdrowia, a także kulturowy kontekst (np. stopień stabuizowania samobójstw i zaburzeń psychicznych) czy warunki ekonomiczne mogą w zasadniczy sposób wpływać na wyniki, utrudniając ich ekstrapolację. W Polsce nie przeprowadzono jednak na taką skalę badań opierających się na wywiadach z rodziną/bliskimi osoby, która popełniła samobójstwo. Analizę przyczyn zachowań samobójczych prowadzono natomiast na mniejszych próbach poprzez wywiady jakościowe z osobami po próbie samobójczej (Ziółkowska, 2016) lub poprzez analizę listów pożegnalnych (Witkowska, 2021). Przegląd zagranicznych badań opartych na analizie skupień wskazuje grupy szczególnie zagrożone samobójstwem, jednak nie wyczerpuje to pełnego obrazu zjawiska - przede wszystkim ze względu na ograniczenia metodologiczne, obecne w literaturze wyniki autopsji psychologicznej często bowiem dotyczą niewielkich grup, są więc niereprezentatywne (Wołodźko, Kokoszka, 2014). W tym kontekście fińskie badanie przeprowadzone przywołaną metodą na tak dużej próbie już w latach 80. XX w. rzeczywiście okazuje się nowatorskie.

Potrzeba lepszego zrozumienia zachowań samobójczych wciąż pozostaje jednak aktualna - z pewnością możemy mówić o grupach podwyższonego ryzyka, jednak decyzja o samobójstwie uwolniona jest od statusu społecznego czy ekonomicznego, poziomu wykształcenia czy wieku (Zwoliński, 2013: 252). Możemy więc uznać, że o ile niektórzy są zagrożeni bardziej, o tyle w ogólnej grupie ryzyka znajdujemy się wszyscy. Od lat toczono rozmowy w celu wdrożenia rozwiązania służącego pozyskaniu większej wiedzy o samobójstwach i próbach samobójczych w Polsce. Zespół 
roboczy do spraw prewencji samobójstw i depresji przy Radzie do Spraw Zdrowia Publicznego podjął w kwietniu 2020 r. uchwałę dotyczącą utworzenia rejestru zachowań samobójczych noszącego miano Krajowej Bazy Danych na rzecz Monitorowania i Profilaktyki Zachowań Samobójczych. Rejestry zachowań samobójczych funkcjonują w niektórych krajach od lat, jednak zasady ich prowadzenia nie są uniwersalne - różnice pojawiają się już przy uprawnieniach koronera czy (nie) obowiązkowości wykonywania sekcji zwłok, a kończą na sposobie klasyfikacji danego przypadku w rejestrach (Värnik et al., 2010). Wątpliwość dotycząca wiarygodności danych statystycznych w zakresie samobójstw wciąż utrzymuje się jednak w świadomości naukowców. Jednym z przykładów może być „ciemna liczba” samobójstw popełnionych na drogach, sklasyfikowanych jako wypadki i nieuwzględnianych w żadnych statystykach, co przyczynia się wciąż do niedoszacowania danych ilościowych (Rosa, 2012).

Inicjatywa utworzenia Krajowej Bazy Danych na rzecz Monitorowania i Profilaktyki Zachowań Samobójczych podzieliła środowisko specjalistów od zdrowia psychicznego w Polsce - Polskie Towarzystwo Psychiatryczne i Polskie Towarzystwo Zapobiegania Samobójstwom wyraźnie sprzeciwiły się takim praktykom, wskazując na ich stygmatyzujący wydźwięk (PTZS, 2020). Nie do końca wiadomo bowiem, w jaki sposób dane te byłyby wykorzystywane w praktyce, w obu opublikowanych stanowiskach znalazł się problem niewłaściwego korzystania z informacji gromadzonych i przetwarzanych w ramach wspomnianego rejestru. Zbieranie tak wrażliwych danych wydaje się niebezpieczne z jeszcze jednego powodu - potencjalnego wycieku czy ataku hakerskiego, jak wydarzyło się jesienią 2020 r. w fińskim Vastaamo (prywatnej klinice świadczącej pomoc psychologiczną i psychiatryczną prywatnie oraz w ramach kontraktów dla publicznej służby zdrowia), z którego bazy danych wykradziono dane przynajmniej 25 tysięcy pacjentów (w tym historie choroby, razem z notatkami z sesji terapeutycznych). Wielu pacjentów padło ofiarami szantażu, dane kilkuset $\mathrm{z}$ nich, w tym dzieci, zostały ujawnione w Internecie (Yle, 2021). Oczywiście fundamentalną rozbieżnością między fińskim a polskim kontekstem jest zasadnicza różnica w poziomie uogólnionego zaufania społecznego, jak i zaufania do instytucji, które w Finlandii należy do najwyższych na świecie.

Z kolei na przykładzie programu KiVa widać, że odpowiednio prowadzona polityka publiczna oparta na uwrażliwianiu zarówno uczniów, jak i kadry pedagogicznej czy rodziców na temat przemocy rówieśniczej może się przyczynić do polepszenia szeroko rozumianych doświadczeń szkolnych i rówieśniczych. W skrajnych sytuacjach szkoła może być przyczyną traumy, a nawet decyzji o zakończeniu życia. I chociaż zjawisko przemocy rówieśniczej wykracza poza szkolne mury, obejmując znacznie szerszy wymiar relacji, to jednak szkoła, zaraz po rodzinie, jest jednym z najważniejszych środowisk kształtujących w młodych osobach postawy 
i wzory funkcjonowania w społeczeństwie. Fiński program KiVa doceniany jest także poza granicami kraju - potraktowanie go jako inspiracji w Polsce wydaje się trudne ze względu na koszty, jednak na pewno uzasadnione. Zgodnie z Ogólnopolska diagnoza problemu przemocy wobec dzieci 59\% dzieci i młodzieży w wieku 11-17 lat doświadczyło przemocy rówieśniczej (Włodarczyk, Makaruk, 2013). Jednocześnie $20 \%$ uczniów będących świadkami przemocy nie zgłasza jej i nie reaguje, jeśli dotyczy ona kogoś innego (Poszwa, Myślińska, 2020). Warto tu również wspomnieć o obustronnej zależności między wiktymizacją a sprawstwem - bycie w jednej roli często przekłada się na późniejsze przyjęcie roli przeciwnej (Walters, 2020). Skala zjawiska oraz jego konsekwencje (w tym te długofalowe) wydają się wystarczające do prowadzenia działań profilaktycznych, których jednym z efektów byłoby przeciwdziałanie zachowaniom autodestrukcyjnym.

\section{$* * *$}

Działania profilaktyczne zawsze uwikłane są w kontekst kulturowy, charakterystyczny dla danej społeczności, niekiedy skierowane są także na specyficzne grupy docelowe, jeżeli jednak są skuteczne, powinny stanowić szerszą inspirację. Być może nierealne jest stworzenie uniwersalnej strategii, jednak można wskazać pewne elementy czy też filary w zakresie właściwej prewencji zachowań samobójczych.

Po pierwsze kluczowe jest przeszkolenie lekarzy pierwszego kontaktu i kadry pielęgniarskiej oraz zadbanie o dostęp do odpowiedniej opieki jednostce w sytuacji kryzysu (wskazuje się także na ograniczenie dostępu do środków, którymi można popełnić samobójstwo - w niektórych krajach chodzi tu np. o pozwolenie na broń) (van der Feltz-Cornelis et al., 2011). Przygotowanie z interwencji kryzysowej (lub jej pogranicza) wydaje się tutaj wyzwaniem zasadniczym:

„Kluczem do prewencji jest poprawa jakości leczenia i diagnozy zaburzeń psychicznych w medycznych placówkach pierwszego kontaktu. Niedawne badania potwierdzają skuteczność i efektywność kosztową psychologicznych i farmakologicznych interwencji w przypadku najczęstszych zaburzeń. (...) Pracownicy placówek pierwszego kontaktu powinni być szkoleni w zakresie diagnozowania i skutecznej terapii” (Patel, Kleinman, 2003: 612-613).

Po drugie skuteczność prewencji opiera się na podejmowaniu różnorodnych działań, których intensyfikacja zmniejszy ogólną liczbę zachowań samobójczych. Głównym założeniem powinno więc być eliminowanie lub chociażby zmniejszanie oddziaływania czynników ryzyka przy jednoczesnym wzmacnianiu czynników ochronnych, bazujących zarówno na wsparciu zewnętrznym, jak i wewnętrznych zasobach jednostki (poprzez chociażby rozwijanie jej zdolności adaptacyjnych czy wypracowanie strategii konstruktywnego radzenia sobie ze stresem). 
Odpowiednia prewencja obecnie wydaje się jeszcze ważniejsza z powodu pandemii COVID-19, która pogorszyła ogólną kondycję psychiczną ludzi (Sokół-Szawłowska, 2021). Specjaliści od zdrowia psychicznego alarmują, że takie doświadczenie może oddziaływać z opóźnieniem, a jego pełne konsekwencje (w tym zespół stresu pourazowego) w odniesieniu do zdrowia psychicznego społeczeństwa możemy poznać dopiero jakiś czas po zażegnaniu kryzysu.

Omawiając problematykę zapobiegania samobójstwom z perspektywy ekonomii moralnej i politycznej, Fitzpatrick w artykule opublikowanym w kwietniu 2021 r. pisze:

"Jako jedno z kluczowych wyzwań stojących przed społeczeństwami zapobieganie samobójstwom wymaga wielostronnego poparcia, uznaje się je za sprawiedliwą i właściwą funkcję państwa i jego instytucji. Praktyczny wymiar zapobiegania samobójstwom wymaga jednak, by brać pod uwagę empiryczne i normatywne aspekty takiego działania. Zapobiegając samobójstwom, staramy się regulować ludzkie zachowania, kierować nimi i zarządzać przez aplikację praktycznej wiedzy. Stąd nie jest to proces pozbawiony wartościowania, ale dotyczy moralnych i politycznych zobowiązań, które wpływają na to, jak postrzega się i rozumie samobójstwo" [w danym społeczeństwie - przyp. aut.] (Fitzpatrick, 2021:2).

Być może każda debata o sposobach zapobiegania samobójstwom powinna wychodzić od tego, w jaki sposób społeczeństwo, a przede wszystkim jego decyzyjne elity, postrzegają samobójstwo, a także jakie są determinanty takiego oglądu. Uzyskanie odpowiedzi na te pytania pozwoli zrozumieć, dlaczego temat samobójstwa w polskich realiach polityczno-moralnych nie jest traktowany z taką powagą jak w innych krajach, również w tych, gdzie skala tego zjawiska jest zdecydowanie mniejsza. Stwierdzenie, że lepiej zapobiegać niż leczyć, jest uznawaną w naukach o zdrowiu zasadą, która jednak często pozostaje na poziomie deklaratywnego sloganu, niewymagającego uzasadnień, ale i nierodzącego żadnych konkretnych konsekwencji. Tymczasem w przypadku profilaktyki samobójstw zapobieganie jest niezbędne, by myśleć o poprawie, na leczenie często nie ma bowiem szans.

\section{Źródło finansowania}

Część danych na potrzeby niniejszego artykułu zgromadzono podczas realizacji projektu badawczego sfinansowanego ze środków Narodowego Centrum Nauki w ramach programu Miniatura 2: Fiński model społeczno-polityczny. Studium socjologiczne. Numer projektu: 2018/02/X/HS5/01828. Kierownik projektu: Wojciech Woźniak. 


\section{Bibliografia}

Aaltonen, K.I., Isometsa, E., Sund, R., Pirkola, S. (2018a). Decline in suicide mortality after psychiatric hospitalization for depression in Finland between 1991 and 2014. World Psychiatry, 17(1): 110-112. DOI: 10.1002/wps.2050.

Aaltonen, K.I., Isometsa, E., Sund, R., Pirkola, S. (2018b). Risk factors for suicide in depression in Finland: first-hospitalized patients followed up to 24 years. Acta Psychiatrica Scandinavica, 139(2): 154-163. DOI: 10.1111/acps.12990.

Adamczyk, P. (2021). Diagnoza: niemiłość? Działania pozorne a system wsparcia dzieci i młodzieży po próbach samobójczych. Przegląd Socjologii Jakościowej, 17(1): 114-134. DOI: $10.18778 / 1733-8069.17 .1 .08$.

Andriessen, K., Krysinska, K. (2019). The portrayal of suicidal behaviour in police television series. Archives of Suicide Research, 24: 1-31. DOI: 10.1080/13811118.2019.1586609.

Appelqvist-Schmidlechner, K. (2011). Time Out! Getting Life Back on Track. A psychosocial support programme targeted at young men exempted from compulsory military or civil service. PhD dissertation. Tampere: University of Tampere, https://repo.tuni.fi/bitstream/ handle/10024/66805/978-951-44-8557-2.pdf? sequence=1\&isAllowed=y (dostęp: 15.02.2021).

Astraud, L., Bridge, J.A., Jollant F. (2021). Thirty Years of Publications in Suicidology: A Bibliometric Analysis. Archives of Suicide Research, 25(4): 751-764. DOI: 10.1080/13811118.2020. 1746944.

Cavanagh, J.T.O., Carson, A.J., Sharpe, M., Lawrie, S.M. (2003). Psychological autopsy studies of suicide: a systematic review. Psychological Medicine, 33(3): 395-405. DOI: 10.1017/ s0033291702006943.

Czabański, A. (2019). Zachowania samobójcze w rodzinach. Społeczne konsekwencje zjawiska. Teologia i Moralność, 14, 2(26): 47-57.

Erling, B. (2019). Samobójstwa w Europie. Dlaczego odbieramy sobie życie?, https://biqdata. wyborcza.pl/biqdata/7,159116,25238980,europa-na-krawedzi-dlaczego-odbieramy-sobie-zycie.html? disableRedirects=true (dostęp: 10.03.2021).

Eurostat (2020). $R$ \&D expenditure, https://ec.europa.eu/eurostat/statistics-explained/index. php/R_\%26_D_expenditure (dostęp: 05.03.2021).

Fitzpatrick S.J. (2021). The moral and political economy of suicide prevention. Journal of Sociology, online ahead of print. DOI: 10.1177/14407833211001112

Fox, C. (2016). Jak - dlaczego - kiedy rozmawiać z młodymi zagrożonymi samobójstwem. Warszawa: Fraszka Edukacyjna sp. z o.o.

Gawliński, A., Sołtyszewski, I., Wiergowski, M. (2020) Epidemiology of suicides in Poland in 1990-2018 - changes and new trends. Archiwum Medycyny Sadowej i Kryminologii, 70(4): 222-234. DOI: https://doi.org/10.5114/amsik.2020.104544

Global Burden of Disease Collaborative Network (2018). Global Burden of Disease Study 2017. Seattle, United States: Institute for Health Metrics and Evaluation.

Goldsmith, S.K., Pellmar, T.C., Bunney, W.E., Kleinman, A. (eds.) (2001). Reducing Suicide: A National Imperative. Washington, DC: National Academies Press. 
Henriksson, M.M., Aro, H.M., Marttunen, M.J., Heikkinen, M.E., Isometsä, E.T., Kuoppasalmi, K.I., Lönnqvist, J.K. (1993). Mental disorders and comorbidity in suicide. American Journal of Psychiatry, 150(6): 935-940. DOI: 10.1176/ajp.150.6.935.

Hjelmeland, H., Dieserud, G., Dyregrov, K., Knizek, B.L., Leenaars, A.A. (2012). Psychological Autopsy Studies as Diagnostic Tools: Are They Methodologically Flawed?. Death Studies, 36(7): 60-626. DOI: 10.1080/07481187.2011.584015.

Höfer, P., Rockett, I.R., Värnik, P., Etzersdorfer, E., Kapusta, N.D. (2012). Forty years of increasing suicide mortality in Poland: Undercounting amidst a hanging epidemic?. BMC Public Health, 12(1). DOI: 10.1186/1471-2458-12-644.

Hofstra, E., van Nieuwenhuizen, Ch., Bakker, M., Özgül, D., Elfeddali, I., de Jong, S.J., van der Feltz-Cornelis, Ch.M. (2020). Effectiveness of suicide prevention interventions: A systematic review and meta-analysis. General Hospital Psychiatry, 63: 127-140. DOI: 10.1016/j. genhosppsych.2019.04.011.

Hołyst, B. (2012). Suicydologia. Wydanie II zmienione i rozszerzone, Warszawa: LexisNexis Polska Sp. z o.o.

Isometsä, E. (2001). Psychological autopsy studies - a review. European Psychiatry, 16(7): 379385. DOI: 10.1016/s0924-9338(01)00594-6.

Isometsä, E. (2017). Suicide Mortality and Suicide Prevention in Finland, http://spkonferens2017. se/wp-content/uploads/2017/09/Finland-suicide-prevention_Isomets\%C3\%A4_130917. pdf (dostęp: 2.03.2021).

Isometsä, E.T., Heikkinen, M.E., Marttunen, M.J., Henriksson, M.M., Aro, H.M., Lönnqvist, J.K. (1995). The last appointment before suicide: is suicide intent communicated?. American Journal of Psychiatry, 152(6): 919-922. DOI: 10.1176/ajp.152.6.919.

Joe, S., Bryant, H. (2007). Evidence-Based Suicide Prevention Screening in Schools. Children \& Schools, 29(4): 219-227. DOI: 10.1093/cs/29.4.219.

Kärnä, A., Voeten, M., Little, T., Alanen, E., Poskiparta, E., Salmivalli, C. (2013). Effectiveness of the KiVa antibullying program: Grades 1-3 and 7-9. Journal of Educational Psychology, 105(2): 535-551. DOI: 10.1037/a0030417.

Knight, P.T., Routti, J. (2012). Information Society and Consensus Formation in Finland. W: National Strategies to Harness Information Technology (77-106), H. Nagy, P.T. Knight (eds.). New York: Springer.

Komenda Główna Policji (2021). Zamachy samobójcze od 2017 roku, https://statystyka.policja. $\mathrm{pl} /$ st/wybrane-statystyki/zamachy-samobojcze/63803, Zamachy-samobojcze-od-2017-roku. html (dostęp: 5.03.2021).

Krysinska, K., Lester, D. (2008). Suicide in the Soviet Gulag Camps. Archives of Suicide Research, 12(2): 170-179. DOI: 10.1080/13811110701857541.

Lewitzka, U., Sauer, C., Bauer, M., Felber, W. (2019). Are national suicide prevention programs effective? A comparison of 4 verum and 4 control countries over 30 years. BMC Psychiatry, 19(158): 1-10. DOI: 10.1186/s12888-019-2147-y.

Lukkari, S., Rautiainen, A. (2013). Metsästäjien kokemuksia Hyvä mehtäkaveri - koulutuksesta Kajaani, https://www.theseus.fi/bitstream/handle/10024/69197/Rautiainen_Arja. pdf? sequence $=1$ \&isAllowed $=y$ (dostęp: 15.03.2021). 
Myllykangas, M. (2019). The History of Suicide Prevention in Finland, 1860 s - 2010 s. W: Preventing Mental Illness. Past. Present and Future (151-170), D. Kritsotaki, V. Long, M. Smith (eds.). Cham: Palgrave Macmillan.

National Mental Health Strategy and Programme for Suicide Prevention 2020-2030(2020). Publications of the Ministry of Social Affairs and Health 2020:15. Helsinki: Ministry of Social Affairs and Welfare, https://julkaisut.valtioneuvosto.fi/bitstream/handle/10024/162234/ STM_2020_15.pdf (dostęp: 6.09.2021).

Nordling, E. (2014). Uusia eväitä metsämiehen reppuun, http://phehkaisevatyo.pbworks.com/w/ file/fetch/85912873/1C_1Nordling.pdf (dostęp: 10.03.2021).

Ohberg, A., Lönnqvist, J.K. (1998). Suicides hidden among undetermined deaths. Acta Psychiatrica Scandinavica, 98(3): 214-218. DOI: 10.1111/j.1600-0447.1998.tb10069.x.

Paasilinna, A. (2007). Fantastyczne samobójstwo zbiorowe. Rusiec: Wydawnictwo Kojro.

Partonen, T. (2016). Suicide prevention in Finland. National Institute for Health and Welfare, https://www.slideshare.net/THLfi/timo-partonen-suicide-prevention-in-finland (dostęp: 15.04.2021).

Partonen, T. (2020). A New National Suicide Prevention Programme in Finland. Psychiatria Fennica, 51: 10-15.

Patel, V., Kleinman, A. (2003). Poverty and common mental disorders in developing countries. Bulletin of the World Health Organization, 81(8): 609-615.

Poszwa, K., Myślińska, D. (2020). Analiza zjawiska przemocy rówieśniczej - teoria i badania własne. Dziecko Krzywdzone. Teoria, Badania, Praktyka, 19(4): 12-25.

PTZS (2020). Stanowisko PTZS $w$ sprawie rejestru prób samobójczych obywateli RP, https:// ptzs.pl/aktualnosci/stanowisko-ptzs-w-sprawie-rejestru-prob-samobojczych-obywateli-rp/ (dostęp: 11.03.2021).

Rosa, K. (2012). (Nie) wiarygodność danych statystycznych dotyczących zachowań samobójczych. Perspektywa teoretyczna i praktyka społeczna. Przeglad Socjologiczny, 61 (2): 265-290.

Ryn, Z. (1986). Suicides in the Nazi Concentration Camps. Suicide and Life-Threatening Behavior, 16(4): 419-422. DOI: 10.1111/j.1943-278X.1986.tb00728.x.

Salmivalli, C., Poskiparta, E., Ahtola, A., Haataja, A. (2013). The implementation and effectiveness of the KiVa antibullying program in Finland. European Psychologist, 18(2): 79-88. DOI: $10.1027 / 1016-9040 / a 000140$.

Shaffer, D., Scott, M., Wilcox, H., Maslow, C., Hicks, R., Lucas, C.P., Garfinkel, R., Greenwald, S. (2004). The Columbia SuicideScreen: Validity and Reliability of a Screen for Youth Suicide and Depression. Journal of the American Academy of Child \& Adolescent Psychiatry, 43(1): 71-79. DOI: 10.1097/00004583-200401000-00016.

Sidz, M. (2020). Kocie chrzciny. Sękowa: Wydawnictwo Czarne.

Sokół-Szawłowska, M. (2021). Wpływ kwarantanny na zdrowie psychiczne podczas pandemii COVID-19. Psychiatria, 18(1): 57-62.

Suominen, K.H., Isometsä, E.T., Ostamo, A.I., Lönnqvist, J.K. (2002). Health care contacts before and after attempted suicide. Social Psychiatry and Psychiatric Epidemiology: The International Journal of Research in Social and Genetic Epidemiology and Mental Health Services, 37(2): 89-94. DOI: 10.1007/s127-002-8220-y. 
van der Feltz-Cornelis, C.M., Sarchiapone, M., Postuvan, V., Volker, D., Roskar, S., Grum, A.T., Carli, V., McDaid, D., O’Connor, R., Maxwell, M., Ibelshäuser, A. (2011). Best Practice Elements of Multilevel Suicide Prevention Strategies. A Review of Systematic Reviews, Crisis. The Journal of Crisis Intervention and Suicide Prevention, 32(6): 319-333. DOI: doi: 10.1027/0227-5910/a000109.

Värnik, P., Sisask, M., Värnik, A., Laido, Z., Meise, U., Ibelshäuser, A., Van Audenhove, C., Reynders, A., Kocalevent, R.D., Kopp, M., Dosa, A. (2010). Suicide registration in eight European countries: A qualitative analysis of procedures and practices. Forensic Science International, 202(1-3): 86-92. DOI: 10.1016/j.forsciint.2010.04.032.

Walters, G.D. (2020). Przemoc rówieśnicza (bullying) wśród osób w wieku szkolnym - wiktymizacja i sprawstwo. Metaanaliza badań prospektywnych. Dziecko Krzywdzone. Teoria, Badania, Praktyka, 19(4): 74-98.

WHO (2021). Suicide rate estimates, age-standardized. Estimates by country, https://apps.who. int/gho/data/node.main.MHSUICIDEASDR?lang=en (dostęp: 2.03.2021).

Witkowska, H. (2021). Samobójstwo w kulturze dzisiejszej. Listy samobójców jako gatunek wypowiedzi i fakt kulturowy. Warszawa: Wydawnictwo Uniwersytetu Warszawskiego.

Włodarczyk, J., Makaruk, K. (2013). Ogólnopolska diagnoza problemu przemocy wobec dzieci. Wyniki badania. Warszawa: Fundacja Dzieci Niczyje.

Wołodźko, T., Kokoszka, A. (2014). Próba klasyfikacji osób podejmujących zachowania samobójcze - przegląd badań z zastosowaniem analizy skupień. Psychiatria Polska, 48(4): 823-834.

Woźniak, W. (2021). Czy można zaprojektować przyszłość? Polityczno-kulturowe korzenie dwudziestowiecznej transformacji Finlandii. Przegląd Socjologii Jakościowej, 17(1): 90-112. DOI: 10.18778/1733-8069.17.1.07.

Yle (2021). Police receive 25,000 crime reports over Vastaamo hacking, https://yle.fi/uutiset/ osasto/news/police_receive_25000_crime_reports_over_vastaamo_hacking/11801245 (dostęp: 20.03.2021).

Ziółkowska, J. (2016). Samobójstwo. Analiza narracji osób po próbach samobójczych. Warszawa: Wydawnictwo Naukowe PWN.

Zwoliński, A. (2013). Samobójstwo jako problem osobisty i publiczny. Kraków: Wydawnictwo WAM.

Unless stated otherwise, all the materials are available under the Creative Commons Attribution 4.0 International license. Some rights reserved to SGH Warsaw School of Economics.

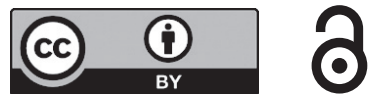

